\title{
26. STABLE ISOTOPIC ANALYSES OF INTERSTITIAL GASES IN QUATERNARY SEDIMENTS FROM THE GULF OF CALIFORNIA ${ }^{1}$
}

\author{
Martin Schoell, Bundesanstalt für Gewissenschaften und Rohstoffe, \\ Stilleweg 2, Hannover, Federal Republic of Germany
}

\begin{abstract}
The origin of the interstitial gases of Hole 479 is bacterial. This is indicated by a positive correlation of the ${ }^{13} \mathrm{C}$ concentration in interstitial methane and $\mathrm{CO}_{2}$ in the shallower depths of the hole. Below a depth of 100 meters, the interstitial $\mathrm{CO}_{2}$ becomes increasingly depleted in carbon-13, which indicates a higher rate of $\mathrm{CO}_{2}$-producing decarboxylation reactions rather than a consumption of $\mathrm{CO}_{2}$ for methane production. Alternatively, dolomite formation could account for an increasing depletion of the interstitial $\mathrm{CO}_{2}$. The interstitial gases in Holes 481 and $481 \mathrm{~A}$ strongly reflect the thermal influence of the dolerite sill. Above the sill, carbon- 13 values of $-52 \%_{0}$ and $C_{2} / C_{1}$ ratios of $10^{-2}$ indicate thermogenically formed hydrocarbon gases. Below the sill, less thermogenic gas formation suggests that convective, rather than conductive, heat transport operated after the sill intruded the wet sediments.
\end{abstract}

\section{INTRODUCTION}

One of the topics of permanent interest for the Deep Sea Drilling Project (DSDP) is the origin of hydrocarbon gases in sediment material. Methane is abundant in areas with high rates of sedimentation in basins near continents. The Gulf of California is an outstanding example: Sedimentation rates of as much as $1200 \mathrm{~m} / \mathrm{m}$.y. were found in the drillholes of Leg 64. This chapter presents isotopic analyses of the interstitial $\mathrm{CH}_{4}$ and $\mathrm{CO}_{2}$ of Holes 479, 481, and 481A.

\section{GEOLOGICAL SETTING}

Holes 479 and 481 were drilled in very young sediment. Hole 479 is on the northeast slope of the Guaymas basin and reaches a total depth of approximately 430 meters through predominantly diatomaceous ooze of a maximum age of about $1 \mathrm{~m} . \mathrm{y}$. The sediments comprise hard layers of dolostones that tend to increase with depth. Hole 481 penetrated 319 meters of upper Quaternary sediments of a maximum age of $\sim 260,000$ years. Mud flows and turbidites account for the high rate of sedimentation in Hole 481. Dolerite sills are intercalated, the most prominent occurring at a depth of 180 to 200 meters. In both holes, the sediments were highly reducing and revealed high alkaline and ammonia content (Gieskes, personal communication). Consistently high concentrations of interstitial methane occur in both holes.

\section{SAMPLING AND EXPERIMENTAL PROCEDURES}

Gas-tight syringes were used to extract gas from gas pockets. The gases were sampled on shipboard, transferred to vacutainers, and forwarded to the laboratory.

We determined the composition of the gas mixtures by gas chromatography. We used a Becker-Packard instrument, equipped with a 100-meter, Squalan-coated, stainless steel capillary column. The following parameters were chosen for analysis: carrier gas

\footnotetext{
${ }^{1}$ Curray, J. R., Moore, D. G., et al., Init. Repts. DSDP, 64: Washington (U.S. Govt.
} Printing Office). helium, oven temperature constant at $60^{\circ} \mathrm{C}$, split 1: $100,100 \mu \mathrm{l}$ injection, flame ionization detector. The peaks $\mathrm{C}_{1}$ through $\mathrm{C}_{6}$ were integrated and normalized to $100 \%$. The results, given in Table 1 , are therefore $\left(1-C_{n} / \sum_{i=1} C_{n}\right) \times 100 \%$ with $n$ as the number of carbon atoms $\mathrm{C}_{1}$ through $\mathrm{C}_{6}$. The detection limit of this procedure is $1.6 \times$ $10^{-9} \mathrm{~mol}$. For isotopic analyses, the air- $\mathrm{CO}_{2}-\mathrm{CH}_{4}$ mixture was processed by attaching a gas chromatograph to a vacuum line; methane and $\mathrm{CO}_{2}$ were separated and $\mathrm{CH}_{4}$ converted to $\mathrm{CO}_{2}$ and $\mathrm{H}_{2}$ for mass spectrometry (Schoell, 1980). Isotopic analyses were performed on VG 903 and Varian MAT 250 instruments. The accuracies of the isotopic analyses were $\delta^{13} \mathrm{C}= \pm 0.1 \%_{0}$ and $\delta \mathrm{D}= \pm 1.5 \%$.

\section{RESULTS AND DISCUSSION}

The results of the isotopic analyses of the interstitial gases are presented in Figures 1 and 2 and are listed in Table 1 . The carbon- 13 concentrations in the methane

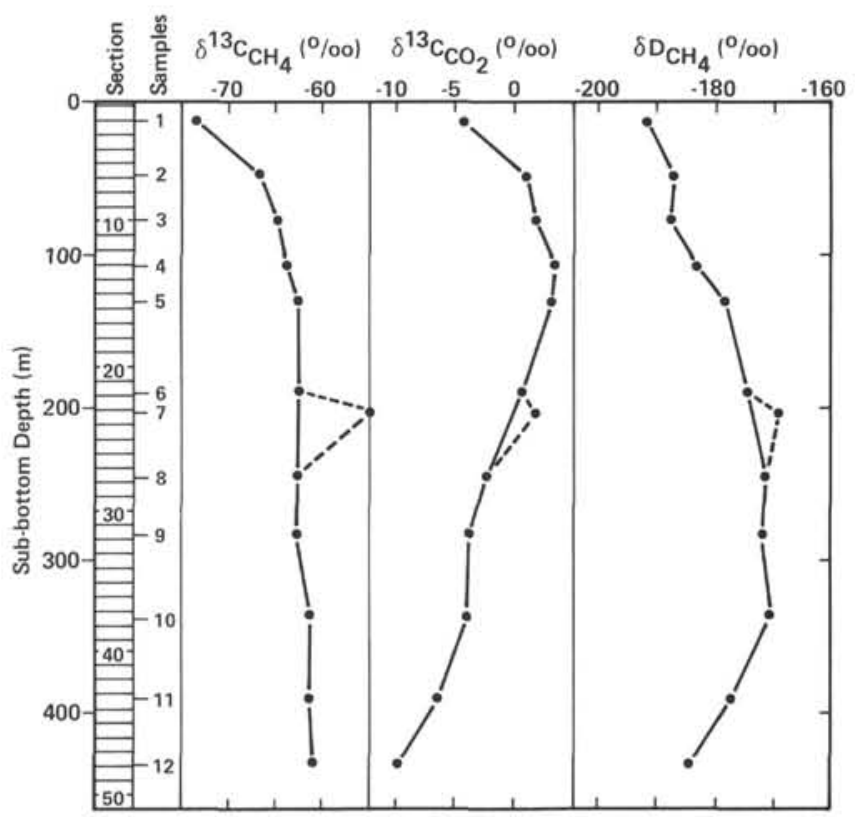

Figure 1. Isotope data from interstitial methane and carbon dioxide, Hole 479. 


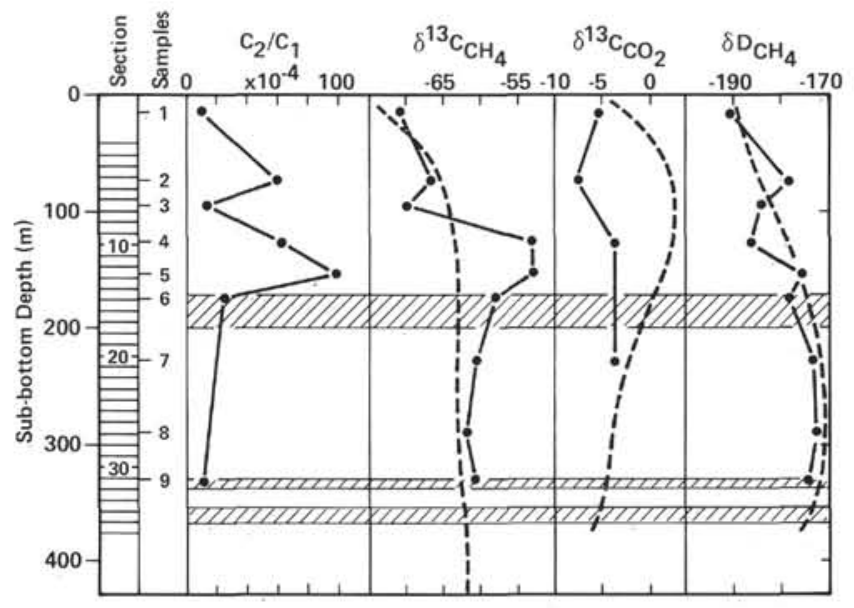

Figure 2. Isotope data from interstitial methane and carbon dioxide, Holes 481 and 481A. (Dashed line gives the trend of the respective parameter in Hole 479 . Values are \% .)

Table 1. Results of isotope analyses on interstitial gases, Holes 479, 481 , and 481A.

\begin{tabular}{|c|c|c|c|c|c|c|c|c|}
\hline Section & $\begin{array}{l}\text { Depth } \\
\text { (m) }\end{array}$ & $\begin{array}{l}\mathrm{CH}_{4} \\
(\%)\end{array}$ & $\begin{array}{c}\mathrm{C}_{2} \mathrm{H}_{6} \\
(\%)\end{array}$ & $\begin{array}{c}\mathrm{C}_{3} \mathrm{H}_{8} \\
(\%)\end{array}$ & $\begin{array}{c}\mathrm{C}_{2} / \mathrm{C}_{1} \\
\left(\times 10^{-4}\right)\end{array}$ & $\begin{array}{c}{ }^{13}{ }^{13} \mathrm{C}_{\mathrm{CH}} \mathrm{CH}_{4} \\
(\%)\end{array}$ & ${ }_{\left.(\%)^{6}\right)}^{\delta D_{C_{4}}}$ & $\begin{array}{c}{ }^{13} \mathrm{C}_{\mathrm{CO}} \\
(\%)\end{array}$ \\
\hline $479-3-1$ & 12.5 & 100.00 & - & - & - & -73.10 & -191 & -4.3 \\
\hline $479-6-4$ & 46.0 & 100.00 & - & - & - & -66.64 & -187 & +1.0 \\
\hline $479-9-4$ & 76.0 & 100.00 & - & - & - & -64.60 & -188 & +1.8 \\
\hline $479-12-6$ & 106.0 & 100.00 & - & - & - & -63.62 & -183 & +3.4 \\
\hline $479-15-2$ & 130.0 & 100.00 & - & - & - & -62.43 & -178 & +3.2 \\
\hline $479-21-5$ & 190.0 & 100.00 & - & - & - & -62.40 & -175 & +0.5 \\
\hline $479-23-5$ & 207.0 & 100.00 & - & - & - & -54.85 & -170 & +1.5 \\
\hline $479-27-5$ & 246.0 & 100.00 & - & - & - & -62.71 & -172 & -2.5 \\
\hline $479-31-5$ & 285.0 & 100.00 & - & - & - & -62.78 & -172 & -3.9 \\
\hline $479-37-4$ & 340.0 & 100.00 & - & - & - & -61.24 & -171 & -4.2 \\
\hline $479-43-2$ & 394.0 & 98.91 & 1.0936 & - & 111 & -61.54 & -178 & -6.7 \\
\hline $479-47-3$ & 435.0 & 99.57 & 0.4267 & - & 43 & -60.99 & -185 & -10.1 \\
\hline 481-P4-1 & 15.8 & 99.88 & 0.1191 & - & 12 & -70.65 & -191 & -5.1 \\
\hline $481 \mathrm{~A}-4-2$ & 72.0 & 99.38 & 0.6185 & - & 62 & -66.31 & -179 & -7.3 \\
\hline $481 A-6-3$ & 93.0 & 99.85 & 0.1489 & - & 15 & -69.43 & -185 & \\
\hline $481 \mathrm{~A}-9-5$ & 125.0 & 99.35 & 0.6501 & - & 65 & -52.57 & -187 & -3.3 \\
\hline $481 \mathrm{~A}-12-5$ & 152.0 & 98.97 & 0.9984 & 0.0272 & 101 & -52.57 & -176 & \\
\hline $481 \mathrm{~A}-16-6$ & 173.0 & 99.75 & 0.2522 & - & 25 & -57.57 & -179 & \\
\hline $481 \mathrm{~A}-20-2$ & 225.0 & 100.00 & - & - & - & -60.29 & -173 & -3.3 \\
\hline $481 \mathrm{~A}-26-6$ & 287.0 & 100.00 & - & - & - & -61.61 & -173 & \\
\hline $481 \mathrm{~A}-30-7$ & 326.0 & 99.85 & 0.1476 & - & 15 & -60.41 & -174 & \\
\hline
\end{tabular}

Note: $-=$ Component was not detected in the GC.

of Hole 479 range from -73 to $-61 \%$, indicating the bacterial origin of the methane. This conclusion is supported by the parallel change of carbon- 13 concentration in the associated $\mathrm{CO}_{2}$. In the upper 100 meters of the drillhole, the $\delta^{13} \mathrm{C}$ values of the $\mathrm{CH}_{4}$ change by approximately $+10 \%$, and the corresponding $\delta^{13} \mathrm{C}_{\mathrm{CO}_{2}}$ values change by $+7 \%$. These changes accord with the predictions of the theoretical model, which assumes the bacterial formation of $\mathrm{CH}_{4}$ by reducing $\mathrm{CO}_{2}$ under closed-system conditions (Claypool and Kaplan, 1974). Below a depth of 100 meters, the $\delta^{13} \mathrm{C}$ values of the methane remain remarkably constant. But the ${ }^{13} \mathrm{C}$ concentration of the $\mathrm{CO}_{2}$ decreases systematically with increasing depth. A similar ${ }^{13} \mathrm{C}$ depletion of the interstitial $\mathrm{CO}_{2}$ has been observed in many other DSDP drillholes (Claypool and Kaplan, 1974). This was attributed to an addition of $\mathrm{CO}_{2}$ from decarboxylation reactions of the organic matter. The interpretation would be appropriate for the data from Hole 479. The decrease in ${ }^{13} \mathrm{C}$ in the interstitial $\mathrm{CO}_{2}$ is not paralleled by a corresponding ${ }^{13} \mathrm{C}$ depletion in the $\mathrm{CH}_{4}$. This could mean that the methane production slowed or even stopped prior to the addition of newly formed $\mathrm{CO}_{2}$. The $\delta^{13} \mathrm{C}_{\mathrm{CO}_{2}}$ shift to more negative values also could be explained by diagenetic reactions such as dolomite formation. Since ${ }^{13} \mathrm{C}$ is concentrated in the carbonate-relative to dissolved or gaseous $\mathrm{CO}_{2}$-an increasing precipitation of dolomite under closed-system conditions could probably explain the ${ }^{13} \mathrm{C}$ shift in the $\mathrm{CO}_{2}$. Other interstitial fluid or carbonate isotope data may support one of the proposed mechanisms.

The $\mathrm{D} / \mathrm{H}$ ratios in the methane are characteristic of biogenic methanes in marine sediments (Schoell, 1980). The $\delta \mathrm{D}$ values increase with depth: from approximately $-190 \%$ to a maximum of $-170 \%$ at a depth of 300 meters. From there downward the deuterium concentrations again decrease. The overall variations of the deuterium concentrations of about $20 \%$ in the methane are not correlated with variations of the D concentrations $(6 \%$ ) in the water. This contrasts with the findings for other biogenic methanes with variations in deuterium primarily controlled by the deuterium variations in the water (Schoell, 1980). The data for Hole 479 suggest that factors other than the $\mathrm{D}$ concentration of the water also must be considered when $\delta \mathrm{D}$ variations in biogenic methane are discussed. Interstitial water chemistry might explain the origin of these effects.

Higher hydrocarbons other than methane were found only in the two lowermost gas samples of Hole 479. This contrasts with the shipboard data and might be explained by a degassing effect described by Galimov (1980), who found more $C_{2}$ hydrocarbon in gases from cores analyzed some time after recovery than in those analyzed immediately after recovery.

The isotope data of the interstitial gases of Holes 481 and $481 \mathrm{~A}$ (Table 1; Fig. 2) are different from those in Hole 479-differences primarily attributable to the thermal influence of the dolerite sill in Hole 479 at 180 to 200 meters.

All gas samples contained significant amounts of ethane but only traces of propane. Again, shipboard data report $\mathrm{C}_{2+}$ hydrocarbons higher than propane in these gases. As noted, the differences might be explained by the degassing effect or experimental differences. The $C_{2} / C_{1}$ ratios are highest 30 meters above the sill and decrease to a very low ratio directly above it. This pattern may be caused by the generation of higher hydrocarbons some distance above the sill and their cracking immediately adjacent to the sill. The ${ }^{13} \mathrm{C}$ concentrations are a good tracer for the onset of thermal processes which form methane. The $\delta^{13} \mathrm{C}$ values at shallow depths are very similar to those in Hole 479. But the values are significantly more positive 30 and 50 meters above the sill where $\delta^{13} \mathrm{C}$ values of $-52 \%$ indicate a large proportion of thermogenic methane mixed with biogenic methane. We can compare the shape of the $\delta^{13} \mathrm{C}$ curve of the thermally affected Holes 481 and $481 \mathrm{~A}$ with the curve of Hole 479 (stippled line in Fig. 2 ). Below the dolerite sill, the $\delta^{13} \mathrm{C}$ values are much closer to those in Hole 479. This indicates that the heat predominantly influenced the sediments above the sillindirect evidence that convection is important when magmatic bodies intrude water-wet sediments. 
The $\delta^{13} \mathrm{C}$ values of the associated $\mathrm{CO}_{2}$ do not change significantly with depth in Holes 481 and $481 \mathrm{~A}$; at corresponding depths in Hole 479, they are generally more positive. It may be that heat above the sill promotes decarboxylation reactions, adding ${ }^{13} \mathrm{C}$-depleted $\mathrm{CO}_{2}$ and shifting the mixed $\mathrm{CO}_{2}$ to more negative $\delta^{13} \mathrm{C}$ values. Alternatively, as noted in the $\delta^{13} \mathrm{C}_{\mathrm{CO}_{2}}$ trend in Hole 479 , carbonate precipitation might explain the more negative $\delta^{13} \mathrm{C}$ values. The addition of $\mathrm{CO}_{2}$ from the magma itself might be another explanation.

The deuterium concentrations of the methane have been only slightly changed in favor of the light isotope $(-187 \%$ in Hole $481 \mathrm{~A}$ versus $-178 \%$ in Hole 479$)$ at the depth of maximum thermal influence above the sill. Below the sill, both holes revealed remarkably similar $\delta \mathrm{D}$ values for the methane. This indicates that thermally produced $\mathrm{CH}_{4}$, which was added to bacterial $\mathrm{CH}_{4}$, had the same deuterium concentration as the bacterial methane. Thermogenic methane, which is associated with crude oil, is indeed within the variation of bacterial gases when D concentrations are considered (Fig. 3). We may conclude that the intruding dolerite sill generated hydrocarbons similar to those associated with crude oils.

Figure 4 compares the interstitial gases from the Gulf of California with those from other DSDP sites such as the Cariaco Trench (Lyon, 1974) and the Cape Verde Rise (Baker et al., 1977). It appears that the methane in the interstitial gases is remarkably uniform in deuterium but has quite a variation in ${ }^{13} \mathrm{C}$. Gases not thermally influenced - and therefore bacteriogenic - have methane $\delta^{13} \mathrm{C}$ values not more positive than $-60 \%$. The genetic field for bacteriogenic methane in the $\delta^{13} \mathrm{C} / \delta \mathrm{D}$ diagram was therefore revised (Fig. 3).

There is a great similarity between interstitial gases from marine sediments and natural gases from young sedimentary basins (Fig. 4). This is strong evidence that the same processes forming interstitial gases also operate in young sedimentary basins where bacterial pro-

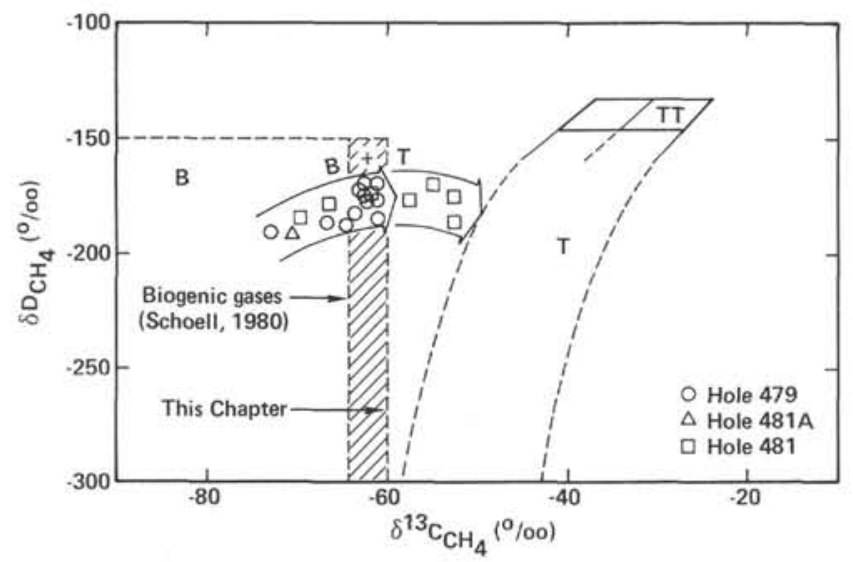

Figure 3. Variations of $\delta^{13} \mathrm{C}$ and $\delta \mathrm{D}$ in the interstitial gases from the Gulf of California in a $\delta^{13} \mathrm{C} / \delta \mathrm{D}$ diagram for natural gases (after Schoell, 1980). ( $\mathrm{B}=$ bacteriogenic gases, $\mathrm{T}=$ thermogenic gases associated with oil, and TT $=$ dry gases not associated with oil.)

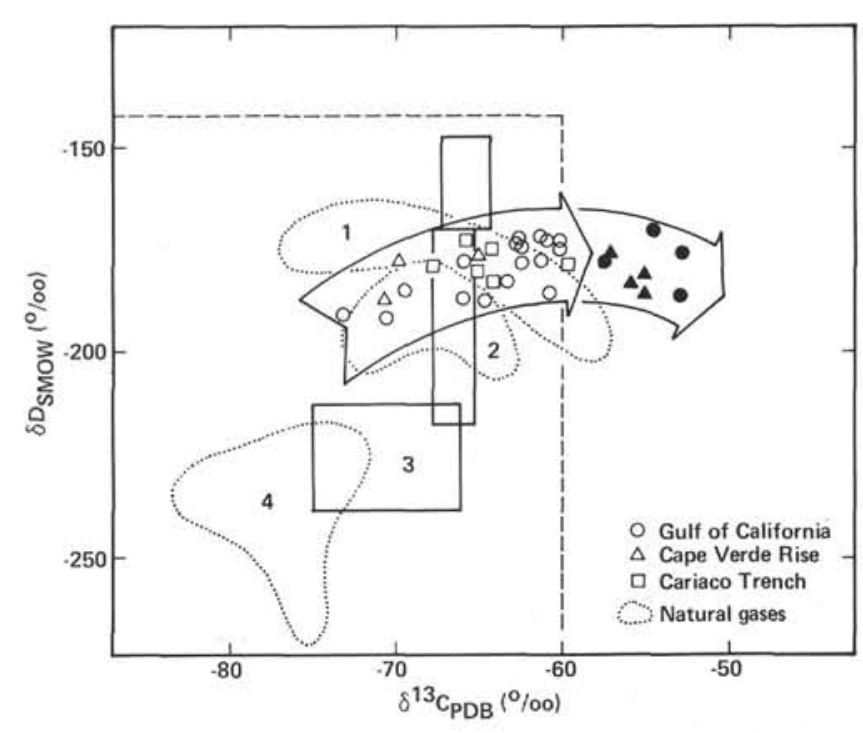

Figure 4. Comparison of isotope variations in methane from interstitial gases in marine sediments and those in natural gases in young sedimentary basins (Schoell, 1980). $(1=$ Po Basin, northern Italy, 2 = South German Molasse Basin, 3 = Bacteriogenic gases, Japan, and 4 = Glacial drift gases.)

cesses eventually form commercial gas accumulations. This similarity argues also for the indigenous character of bacterial gases in immature basins - evidence against the assumption that gases in Tertiary basins generally stem from deep gases that have migrated into immature strata (Neglia, personal communication).

From these comparisons we conclude that the Gulf of California is the prototype of a sedimentary environment where the formation of bacterial gas is virtually ubiquitous. Similar conditions must have prevailed in many young sedimentary basins such as the Po or the South German Molasse.

\section{ACKNOWLEDGMENTS}

I express my special thanks to Bernd Simoneit and Joris Gieskes for performing the sampling on board the Glomar Challenger and for reviewing the manuscript. I also thank $U$. Rinow for performing the isotopic analysis and M. Schmitt for conducting the GC analysis.

\section{REFERENCES}

Baker, E. W., Huang, W. Y., Rankin, J. G., et al., 1977. Electron paramagnetic resonance study of thermal alteration of kerogen in deep sea sediments by sill intrusion. In Lancelot, Y., and Seibold, E., et al., Init. Repts. DSDP, 41: Washington (U.S. Govt. Printing Office), 839-847.

Claypool, G. E., and Kaplan, I. R., 1974. The origin and distribution of methane in marine sediments. In Kaplan, I. R. (Ed.), Natural Gases in Marine Sediments: New York (Plenum), pp. 99-139.

Galimov, E. M., Chinyonof, V. A., and Ivanov, Y. N., 1980. Isotopic composition of methane carbon and the relative content of gaseous hydrocarbons in the deposits of the Moroccan Basin of the Atlantic Ocean, (Deep Sea Drilling Project Sites 415 and 416). In Lancelot, Y., and Winterer, E. L., et al., Init. Repts. DSDP, 50: Washington (U.S. Govt. Printing Office), 615-622.

Lyon, C. L., 1974. Isotopic analyses of gas from the Curiaco Trench sediments. In Kaplan, I. R. (Ed.), Natural Gases in Marine Sediments: New York (Plenum), pp. 91-97.

Schoell, M., 1980. The hydrogen and carbon isotopic composition of methane from natural gases of various origins. Geochim. Cosmochim. Acta, 44:649-661. 